(c) Group of authors, 2019

UDC 616.329-089

DOI - https://doi.org/10.14300/mnnc.2019.14113

ISSN - 2073-8137

\title{
AN INTEGRATED APPROACH TO THE TREATMENT OF COMPLICATED FORMS OF HIATAL HERNIA TAKING INTO ACCOUNT THE PATIENT'S INDIVIDUAL FEATURES
}

\author{
Cherkasov D. M., Cherkasov M. F., Tat'yanchenko V. K., \\ Melikova S. G., Starcev Yu. M., Shamik V. B. \\ Rostov State Medical University, Rostov-on-Don, Russian Federation \\ КОМПАЕКСНЫЙ ПОАХОА В АЕЧЕНИИ ОСАОЖНЕННЫХ ФОРМ \\ ГРЫЖ ПИЩЕВОАНОГО ОТВЕРСТИЯ АИАФРАГМЫ С УЧЕТОМ \\ ИНАИВИАУААЬНЫХ ОСОБЕННОСТЕЙ ПАЦИЕНТА
}

\author{
А. М. Черкасов, М. Ф. Черкасов, В. К. Татьянченко, \\ С. Г. Меликова, Ю. М. Старцев, В. Б. Шамик \\ Ростовский госуАарственный меАицинский университет, Ростов-на-Аону, \\ Российская ФеАерация
}

\begin{abstract}
We describe the treatment of 163 patients with complicated hiatal hernia. The research objective was to increase efficiency of treatment of patients with complicated forms of hiatal hernia using an integrated approach that takes into account specific features of the patient. Patients were divided according to body type. The integrated approach to the treatment of complicated forms of hiatal hernia included: conservative therapy, surgical treatment (Nissen or Nissen-Rossetti surgery), treatment control (endoscopy) for Barrett's esophagus (esophageal mucosal metaplasia) and subsequent courses of argon-plasma coagulation. Based on anatomical studies and CT data, we found that the area of the defect in the esophageal opening of the diaphragm is more pronounced in mature and elderly people with a brachymorphic body type. In these cases, as well as for large and giant hiatal hernias, plastics with own tissues may be insufficient and lead to relapse. To reduce recurrence, we developed a combined method of plastic surgery and back cruroraphy with use of a mesh.
\end{abstract}

Keywords: hiatal hernia, gastroesophageal reflux disease, diaphragm, body type

Представлены результаты лечения 163 пациентов с осложненными грыжами пищеводного отверстия диафрагмы (ГПОД). Цель исследования состояла в повышении эффективности лечения больных с осложненными формами ГПОД при комплексном подходе с учетом индивидуальных особенностей больного. Все пациенты были разделены в зависимости от типа телосложения. Комплексный подход в лечении осложненных форм грыж пищеводного отверстия диафрагмы включал как консервативную терапию, так и антирефлюксные операции, последующий эндоскопический контроль, при пищеводе Барретта - последующие курсы аргон-плазменной коагуляции. На основании анатомических исследований и данных спиральной компьютерной томографии выяснили, что зона дефекта пищеводного отверстия диафрагмы более выражена у лиц брахиморфного типа телосложения во II зрелом и пожилом возрастах. Поэтому в данных случаях, а также при больших и гигантских грыжах пищеводного отверстия диафрагмы пластики собственными тканями может быть недостаточно в связи с вероятностью возникновения рецидива. Для уменьшения рецидивов нами разработан комбинированный способ пластики пищеводного отверстия диафрагмы сетчатым имплантом в сочетании с задней крурорафией.

Ключевые слова: ГЭРБ, грыжи пищеводного отверстия диафрагмы, диафрагма, тип телосложения

For citation: Cherkasov D. M., Cherkasov M. F., Tat'yanchenko V. K., Melikova S. G., Starcev Yu. M., Shamik V. B. AN INTEGRATED APPROACH TO THE TREATMENT OF COMPLICATED FORMS OF HIATAL HERNIA TAKING INTO ACCOUNT THE PATIENT'S INDIVIDUAL FEATURES. Medical News of North Caucasus. 2019;14(3):469-472. DOI - https://doi.org/10.14300/mnnc.2019.14113

Для цитирования: Черкасов Д. М., Черкасов М. Ф., Татьянченко В. К., Меликова С. Г., Старцев Ю. М., ШаМИК В. Б. КОМПЛЕКСНЫЙ ПОДХОД В ЛЕЧЕНИИ ОСЛОЖНЕННЫХ ФОРМ ГРЫЖ ПИЩЕВОДНОГО ОТВЕРСТИЯ ДИАФРАГМЫ С УЧЕТОМ ИНДИВИДУАЛЬНЫХ ОСОБЕННОСТЕЙ ПАЦИЕНТА. МЕДИЦИНСКИЙ ВеСтНИК СеверНОГО КавКаза. 2019;14(3):469-472. DOI - https://doi.org/10.14300/mnnc.2019.14113 
H iatal hernias are one of the most common pathologies of the gastrointestinal tract $[1,2]$. This nosology is especially relevant given the significant increase in complications of gastroesophageal reflux disease in recent years [3], noted both in Europe and Russia. According to the education centre for 'Epidemiology of gastroesophageal reflux in Russia,' heartburn occurs in $47.5 \%$ of respondents, and the prevalence of GERD is $13.3 \%$ [4]. In the pathogenesis of reflux esophagitis, there are several disorders of cardiac valve devices and the anatomy of the esophageal opening of the diaphragm, specifically of the physiological violation of the diaphragm legs involved in the formation of the esophageal opening of the diaphragm [5]. An important stage of surgical treatment is the elimination of the defect in the esophageal opening of the diaphragm, in which mesh materials play an essential role [6, 7]. The consequence of reflux esophagitis may include complications such as esophageal ulcers, peptic strictures, and Barrett's esophagus, an obligate precancer [8]. Barrett's esophagus is detected in $15 \%$ of patients with reflux esophagitis [9].

The research objective was to increase the efficiency of treatment of patients with complicated forms of hiatal hernia using an integrated approach taking into account specific features of the patient.

Material and Methods. A total of 163 patients with complicated forms of hiatal hernia were studied. A slight predominance of women was noted: 92 females (56.4 \%) in contrast with 71 males (43.6 \%), although no statistically significant difference between these two groups was found, which is consistent with the literature. In the sample, $85.9 \%$ of patients were over 36 years of age

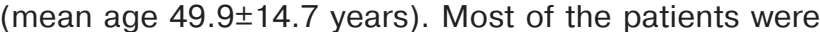
of the most economically active age. Due to differences in the surgical treatment of complicated forms of hiatal hernia, we divided patients according to their body type (Table 1).

The distribution of patients by body type

\begin{tabular}{|l|c|}
\hline \multicolumn{1}{|c|}{ Body type } & Number of patients $(\mathrm{n}=163)$ \\
\hline Dolichomorphic & 27 \\
\hline Mesomorphic & 85 \\
\hline Brachymorphic & 51 \\
\hline
\end{tabular}

Table 1 shows that the most frequently complicated forms of hiatal hernia were found in people with mesomorphic body types. Patients complained of heartburn, chest pain, epigastric pain, belching, regurgitation, and coughing.

Patients with one or more complications of hiatal hernia were included in our observations (Table 2).

Table 2

Complications of hiatal hernia in the examined patients

\begin{tabular}{|l|c|c|}
\hline \multirow{2}{*}{\multicolumn{1}{c|}{ Complications }} & \multicolumn{2}{c|}{$\begin{array}{c}\text { Number of patients } \\
(\mathrm{n}=163)\end{array}$} \\
\cline { 2 - 3 } & $\mathrm{N}$ & $\%$ \\
\hline Reflux esophagitis & 163 & 100 \\
\hline Erosion & 23 & 14,1 \\
\hline Barrett's esophagus & 21 & 12,9 \\
\hline Gastric metaplasia & 9 & 5,5 \\
\hline Stenosis & 6 & 3,7 \\
\hline Infringement & 1 & 0,6 \\
\hline
\end{tabular}

Esophagogastroduodenoscopy, X-ray in vertical, horizontal and Trendelenburg position, intraluminal pH-metry, esophagomanometry, and CT were used for diagnosis, and to determine qualification forms, stages of the disease, and nature of the complications. Endoscopic examination revealed reflux esophagitis in all patients, predominating in patients with a reflux esophagitis stage $B$ and $C(n=114,69.9 \%)$. When identifying suspicious areas, target biopsies were performed, as well as the four-quadrant method of biopsy every $2 \mathrm{~cm}$ according to the standard Prague method.

The calculation of statistical data was made on a personal computer using Microsoft Excel 2016 and the statistical program $\mathrm{R}$ (version 3.2, R Foundation for Statistical Computing, Vienna, Austria).

Results and Discussion. An integrated approach to the treatment of complicated forms of hiatal hernia includes drug therapy, surgical treatment (Nissen or Nissen-Rossetti surgery), control of treatment (endoscopy) for Barrett's esophagus (esophageal mucosal metaplasia) with subsequent courses of argonplasma coagulation [10,11].

All patients received drug therapy before surgery and followed a diet for 1.5 to 10 years. The diet required compliance at mealtimes, eating food in small fractional portions with the last meal no later than four hours before sleep. It excluded carbonated drinks and alcohol. Products that enhance the secretions of the stomach were also reduced. All patients were recommended to stop smoking, eliminate factors that lead to increased intra-abdominal pressure (e.g., constipation, coughing, difficulty urinating, muscle tension of the anterior abdominal wall, and wearing tight clothes). The main groups of drug therapy were antisecretory, antacids, and prokinetic medications. With the lack of effectiveness of conservative treatment and the absence of a significant positive result, surgical treatment was performed: Nissen or Nissen-Rossetti operations. Like most surgeons, we prefer to perform this surgical treatment from laparoscopic access [6, 12, 13]. After mobilization of the esophagus, the bottom of the stomach and the legs of the diaphragm, the posterior cruroraphy was performed. Then a fundoplication cuff of $3-4 \mathrm{~cm}$ in size was superimposed. In the case of large and giant hiatal hernias, the esophageal opening of the diaphragm was performed using a mesh implant.

There is constitutional variability in the length of the inner legs of the diaphragm, linked to different body type. The brachymorphic body type in men and women is 2.0$2.5 \mathrm{~cm}$ more than the dolichomorphic type, and 1.0-1.5 $\mathrm{cm}$ more than the mesomorphic body type $(p<0.05)$. The changes revealed in the parameters of the inner legs of the diaphragm influenced the size of the esophageal opening of the diaphragm in persons with different constitutional body types. In the case of a brachymorphic body type, the size of the esophageal opening of the diaphragm exceeds those of persons with dolicho- and mesomorphic body types. It is known that in people older than 35 years, especially in persons of the brachymorphic body type, the amount of fiber near the esophageal opening of the diaphragm decreases. This leads to a decrease in the elasticity of the fascial structures in the area of the esophageal opening of the diaphragm. Age-related changes are accompanied by a change in angioarchitectonics, specifically a decrease in the diameter of the main arteries feeding the diaphragm. In conditions of local ischemia of the fascia-muscular structures in the area of the esophageal opening of the diaphragm, we consider plastics using a mesh to be more effective. We place the mesh in the posterior mediastinum in the case of large and giant hiatal hernias in patients with a brachymorphic body type in the second mature and 
elderly stages of life. The proposed method using a mesh implant helps to strengthen the area of the esophageal opening of the diaphragm, and the subsequent posterior cruroraphy covers the mesh implant and prevents it from contacting both the wall of the esophagus and the abdominal organs (a patent of the Russian Federation № 2611912, published 01.03.2017). This allows us to avoid a number of complications associated with finding a mesh in the abdominal cavity $[6,14]$.

The selection criteria for placing the mesh were the body type of the patient, the area size of the esophageal opening of the diaphragm, and thinning of the diaphragm legs (according to CT) (Table 3).

Table 3

Algorithm for the use of mesh implant in patients of the mature II and elderly age

\begin{tabular}{|l|c|c|c|c|}
\hline \multicolumn{1}{|c|}{ Body type } & $\begin{array}{c}\text { Small } \\
\text { hernia }\end{array}$ & \multicolumn{2}{|c|}{ Big hernia } & Giant hernia \\
\hline Brachymorphic & V-lock & \multicolumn{2}{|c|}{ Mesh implant } & Mesh implant \\
\hline Mesomorphic & V-lock & $\begin{array}{c}\text { V-lock } \\
\text { +Vicryl }\end{array}$ & $\begin{array}{c}\text { Mesh } \\
\text { implant }\end{array}$ & Mesh implant \\
\hline Dolichomorphic & V-lock & \multicolumn{2}{|c|}{ V-lock +Vicryl } & Mesh implant \\
\hline
\end{tabular}

Complications in patients with hiatal hernia who underwent surgical treatment can be divided into intraoperative, early (up to three months) and late (more than three months). In 9 cases of 163 patients conversion was performed, caused by bleeding $(n=6 ; 3.7 \%)$; pronounced adhesions ( $n=2 ; 1.2 \%)$, and perforation of the esophagus $(n=1 ; 0.6 \%)$. Early postoperative complications observed in patients included dysphagia, hiccups, gas-bloat, dyspeptic symptoms, seroma of one of the postoperative wounds, small hydrothorax, and postoperative pneumonia. All complications were classified as I severity and did not require additional treatment. When using mesh, complications in the early postoperative period occurred slightly more frequently than with plastic using own tissues (10.3 \% vs. $3.3 \%)$.

In the long-term, postoperative complications may be a relapse of hiatal hernia, the phenomenon of 'slipping cuff', fundoplication cuff migration to the mediastinum, cuff hyperfunction, and gastroesophageal reflux. Longterm postoperative complications were observed in $9.4 \%$ cases when using plastics with only own tissues and in $2.6 \%$ of cases when using plastic with mesh.
We analyzed results of the videoendosurgical treatment of complicated forms of hiatal hernia in patients with plastic by own tissues and using a mesh implant using a questionnaire about the level of health of patients with GERD (GERD-HRQL). In assessing quality of patients' lives according to the GSRS questionnaire, abdominal pain syndrome, reflux syndrome, and dyspeptic syndrome were evaluated, as well as a total score.

The questionnaire was given to patients with plastics by their tissues before surgery (124 people), and then following surgery at 3,6 , and 12 months, and after 3 and 5 years. After three months, 119 of 124 patients were examined; after 6 and 12 months, 117 patients; after three years, 78 patients, and after five years, 44 patients.

Questionnaires of patients with plastic using a mesh (39 people) were completed directly before surgery. After surgery at 3,6 , and 12 months all 39 patients were examined; after three years, 21 patients; and after five years, nine patients. The GERD-HRQL and GSRS questionnaires of both groups revealed that the decreased values in the patients studied continued up to 12 months of the postoperative period, and then the values became permanent.

In 30 patients with metaplasia of the esophageal mucosa in the postoperative period, endoscopic argon-plasma coagulation of the area of esophageal metaplasia was performed after 1-2 months. This procedure was carried out in FORCED mode (power 30-32 W with argon rate 2$2.2 \mathrm{l} / \mathrm{min}$ ) with subsequent drug therapy. Depending on the size of the area of metaplastic changes, $2-5$ procedures were performed with an interval of 1-1.5 months. Endoscopic control of healing was carried out a month after performing argon-plasma coagulation.

Conclusions. Treatment of complicated forms of hiatal hernia should have an integrated approach, which should begin with drug therapy. Based on anatomical studies, we found that the area of the defect in the esophageal opening of the diaphragm, as shown by CT data, is more pronounced in persons of the brachymorphic body type in the second mature and elderly age. Thus, in these cases, as well as for large and giant hiatal hernias, the plastic diaphragm by its own tissues may not be adequate and may lead to recurrence. Therefore, we recommend in these cases that our surgical method be used to prevent a recurrence. This approach consists of setting mesh in the posterior mediastinum and covering this mesh through performing posterior cruroraphy. When Barrett's esophagus is detected, argon-plasma coagulation is performed.

\section{Disclosures:}

The authors declare no conflict of interest.

\section{References}

1. Wallner B Björ O Andreasson A Hellström P. M., Forsberg A. M. [et al.] Identifying clinically relevant sliding hiatal hernias: a population-based endoscopy study. Scand. J. Gastroenterol. 2018;53(6);657-660. https://doi.org/10.1080/00365521.2018.1458896

2. Kotiev B. N., Pryadko A. S., Vasilevskiy D. I., Silant'ev D. S. The MESH-technologies in surgical treatment of hiatal hernia and gastroesophageal reflux. Khirurgiya. Zhurnal im. N. I. Pirogova. 2012;4:59-62.

3. Zyabreva I. A., Dzhulaj T. E. Hiatal hernia: controversial, unsettled and prospective aspects (literature review). Verhnevolzhskij medicinskij zhurnal. 2015;14(4):24-28.

4. Lazebnik L. B., Masharova A. A., Bordin D. S., Vasil'ev Yu. V., Tkachenko E. I. [et al.] Multicenter study «Epidemiology of gastroesophageal reflux disease in Russia» (MEGRE): first results. Eksperimental'naya i klinicheskaya gastroenterologiya. 2009;6:4-12.

5. Souza M., Nobre R. A., Bezerra P. C., Dos Santos A. A. Sifrim D. Anatomical and functional deficiencies of the crural diaphragm in patients with esophagitis. Neurogastroenterol Motil. 2017;29(1):1-8. https://doi.org/10.1111/nmo.12899

6. Koch O. O., Asche K. U., Berger J., Weber E., Granderath F. A., Pointner R. Influence of the size of the hiatus

on the rate of reherniation after laparoscopic fundoplication and refundopilication with mesh hiatoplasty. Surg. Endosc. 2011:25:1024-1030.

https://doi.org/10.1007/s00464-010-1308-3

7. Carpelan-Holmstrom M., Kruuna O., Salo J., Kylanpaa L., Scheinin T. Late mesh migration through the stomach wall after laparoscopic refundoplication using a dual-sided PTFE/ePTFE mesh. Hernia. 2011:15:217-220. https://doi.org/ 10.1007/s10029-010-0633-8

8. Ungureanu S., Șipitco N., Gladun N., Lepadatu C. Paraesophageal hernia repair with bifacial mesh. Journal of Medicine and Life. 2016;9(1):66-69.

9. Nandipati K., Bye M., Yamamoto S. R., Pallati P., Lee T., Mittal S. K. Reoperative intervention in patients with mesh at the hiatus is associated with high incidence of esophageal resection--a single-center experience. J. Gastrointest. Surg. 2013:17(12):2039-2044. https://doi.org/10.1007/s11605-013-2361-8

10. Antonakis F., Kockerling F., Kallinowski F. Functional Results after Repair of Large Hiatal Hernia by Use of a Biologic Mesh. Front. Surg. 2016;3:16.

https://doi.org/10.3389/fsurg.2016.00016

11. Cherkasov D. M., Cherkasov M. F., Startsev Yu. M., Melikova S. G. Modern approach to the treatment of com- 
plicated hiatal hernias. Endoskopicheskaya hirurgiya. 2016;22(2):14-17

12. Tam V., Winger D. G., Nason K. S. A systematic review and meta-analysis of mesh versus suture cruroplasty in laparoscopic large hiatal hernia repair. Am. J. Surg. 2016;211(1):226-238

https://doi.org/10.1016/j.amjsurg.2015.07.007
13. Cherkasov M. F., Startsev Yu. M., Cherkasov D. M. Abdominal'naya hirurgiya. Nacional'noe rukovodstvo: kratkoe izdanie. Pod red. I.I. Zatevahina, A. I. Kirienko, V. A. Kubyshkina. M.: GEOTAR-Media; 2016

14. Chernousov A. F., Horobryh T. V., Vetshev F. P. Repeated antireflux surgery. Vestnik hirurgicheskoj gastroenterologii. $2011 ; 3: 4-15$

\begin{abstract}
About authors:
(C) Trushin P. V., 2019

UDC 617-089.844:546.82-034.24-19

DOI - https://doi.org/10.14300/mnnc.2019.14114

ISSN - 2073-8137
\end{abstract}

Cherkasov Denis Mihajlovich, MD, PhD, Associate Professor of the Department of surgical diseases № 2 ; tel.: +79185003275; e-mail: doctor1012@ramblerl.ru; ORCID - 0000-0003-0320-7923

Cherkasov Mihail Fedorovich, MD, PhD, Professor, Head of the Department of surgical diseases; tel.: +79188923200; e-mail: cherkasovmf@mail.ru; ORCID - 0000-0001-7587-8406

Tat'yanchenko Vladimir Konstantinovich, MD, PhD, Professor, Head of the Department of operative surgery, clinical anatomy and pathological anatomy; tel.: +79185010595; e-mail: vladimirtatyanchenko@mail.ru; ORCID - 0000-0002-7407-2686

Melikova Sabina Gadzhievna, senior laboratory assistant of the Department of surgical diseases; tel.: +79185155832; e-mail: sarbonka@bk.ru; ORCID - 0000-0002-1966-1664

Starcev Yurij Mihajlovich, PhD, Associate Professor of the Department of surgical diseases; tel.: +79289541816; e-mail: starcevvv111@mail.ru; ORCID - 0000-0002-5769-4598

Shamik Viktor Borisovich, DMSc, Professor, Professor of the Department of pediatric surgery and orthopedics; tel.: +79188923200; e-mail: prof.shamik@gmail.com; ORCID - 0000-0002-0461-8700

\title{
APPLICATION OF FINELY GRANULATED TITANIUM NICKELIDE IN SURGICAL PRACTICE
}

Trushin P. V.

\author{
Novosibirsk State Medical University, Russian Federation
}

\section{ПРИМЕНЕНИЕ МЕАКОГРАНУАИРОВАННОГО НИКЕАИАА ТИТАНА В ХИРУРГИЧЕСКОЙ ПРАКТИКЕ}

\section{П. В. Трушин}

\section{Новосибирский госуАарственный меАицинский университет, Российская ФеАерация}

A clinical study involved 90 patients with chronic osteomyelitis. Patients were divided into two groups. In group I, 60 patients underwent sequestrectomy and plastic surgery of the sequestral cavity with finely granulated titanium nickelide. In group II, 30 patients after sequestrectomy, the bone cavity was filled in the traditional way (hemoplasty). Both in the early postoperative period and the long follow-up period, the clinical and radiological effects of the proposed methodology for treating residual bone cavities were confirmed. When using titanium nickelide implants, the formation of biocomposite is observed in patients, which ensures the preservation of bone strength. This prevents the occurrence of pathological fractures. Titanium nicelide is characterized by mechanical strength, has osteoconductive properties and allows sufficient filling of cavities with complex anatomical structure. Also, preservation of congruence of composite with bone tissue during bone growth (in case of treatment of children) is noted.

Keywords: dystrophic bone cysts, chronic osteomyelitis, plasty, titanium nickelide

В клиническом исследовании участвовали 90 пациентов с хроническим остеомиелитом. Пациенты были разделены на 2 группы. В группе I у 60 пациентов выполнялась секвестрэктомия и пластика секвестральной полости мелкогранулированным никелидом титана. В группе II у 30 пациентов после секвестрэктомии костная полость заполнялась традиционным способом (гемопломбой). Как в раннем послеоперационном периоде, так и в отдаленном периоде наблюдения подтверждается клинико-рентгенологическая эффективность предлагаемой методики лечения остаточных костных полостей. При использовании имплантатов из никелида титана наблюдается формирование у пациентов биокомпозита, который обеспечивает сохранение прочности кости. Это предотвращает возникновение у больных патологических переломов. Никелид титана отличается механической прочностью, обладает остеокондуктивными свойствами и позволяет эффективно заполнять полости, имеющие сложную анатомическую структуру. Помимо этого, отмечено сохранение конгруэнтности композита с костной тканью в процессе роста кости (в случае проведения лечения детей).

Ключевые слова: дистрофические костные кисты, хронический остеомиелит, пластика, никелид титана 